\title{
ResearchOnline@JCU
}

This is the author-created version of the following work:

Goodman, Nigel, Nematollahi, Neda, and Steinemann, Anne (2020) Fragranced laundry products and emissions from dryer vents: implications for air quality and health. Air Quality, Atmosphere and Health, 14 pp. 245-249.

Access to this file is available from:

https://researchonline.jcu.edu.au/64706/

(c) Springer Nature B.V. 2020

Please refer to the original source for the final version of this work: http://dx.doi.org/10.1007/s11869\%2D020\%2D00929\%2D0 
Goodman N, Nematollahi N, Steinemann A. 2020. Fragranced Laundry Products and Emissions from Dryer Vents: Implications for Air Quality and Health. Air Quality, Atmosphere \& Health, DOI: https://doi.org/10.1007/s11869-020-00929-0

\section{Fragranced laundry products and emissions from dryer vents: \\ implications for air quality and health}

\section{Nigel Goodman*, Neda Nematollahi, and Anne Steinemann}

*Corresponding author: Nigel Goodman

nigel.goodman@rmit.edu.au

\section{Nigel Goodman*}

Vice Chancellor's Postdoctoral Research Fellow, School of Property Construction and Project Management, RMIT University, Melbourne VIC 3000 Australia

\section{Neda Nematollahi}

Postdoctoral Research Fellow, Department of Infrastructure Engineering, Melbourne School of Engineering, The University of Melbourne, Parkville Victoria 3010 Australia

\section{Anne Steinemann}

Professor of Civil Engineering, Department of Infrastructure Engineering, Melbourne School of Engineering, The University of Melbourne, Parkville Victoria 3010 Australia

Professor of Engineering, Chair of Sustainable Infrastructure, College of Science and Engineering, James Cook University, Townsville Queensland 4814 Australia

Keywords: Laundry products . Fragranced consumer products . Dryer vents . Indoor air quality . Outdoor air quality. Health effects . Volatile organic compounds. Terpenes

This is a pre-print of an article published in Air Quality, Atmosphere \& Health. The final authenticated version is available online at: https://doi.org/10.1007/s11869-020-00929-0 


\begin{abstract}
Fragranced laundry products emit numerous volatile organic compounds (VOCs), including terpenes such as limonene. Fragrance emissions have been associated with adverse health effects such as asthma attacks and breathing difficulties. Further, fragrance terpenes are primary indoor air pollutants that can react with other compounds and contribute to both indoor and outdoor air pollution. This paper examines volatile emissions and exposures from fragranced laundry products, and the implications for air quality and health. The paper synthesises and analyses data from studies conducted across the United States (US) and Australia (AU), providing results in three main themes: adverse health effects associated with exposure to fragranced laundry products, volatile emissions from fragranced and fragrancefree laundry products, and reductions in VOC emissions by switching from fragranced to fragrance-free products. Across the US and AU, $12.5 \%$ and $6.1 \%$ of the general population and $28.9 \%$ and $12.1 \%$ of asthmatics report health problems (respectively) when exposed to scented laundry products coming from a dryer vent. Among the volatile emissions from products, terpenes were the most prevalent VOCs detected in all fragranced laundry products; however, terpenes were absent in all fragrance-free products. By switching from fragranced to fragrance-free laundry products, dryer vent emissions of limonene can be reduced up to 99.7\%. As context for significance, switching from fragranced to fragrance-free laundry detergent could reduce limonene emissions from dryer vents per household by an estimated 1.68 grams/year. For the study area of metropolitan Melbourne, this represents a reduction in limonene emissions by an estimated 1.58 tons/year. Results from these analyses point to a promising way to reduce emissions and exposures to volatile compounds, and create potential improvements for air quality and health.
\end{abstract}




\section{Introduction}

Emissions from fragranced laundry products, such as terpenes (e.g., limonene and alphapinene), are an important source of both indoor and outdoor air pollution (Steinemann 2015). Within indoor environments, such as homes, terpenes are consistently among most abundant pollutants (e.g., Goodman et al. 2017; Jia et al. 2008; Wang et al. 2017). Further, terpenes react with ozone to generate additional and potentially hazardous pollutants, such as formaldehyde and ultrafine particles (Nazaroff and Weschler 2004). In outdoor environments, terpenes emitted from laundry products contribute to VOCs (Steinemann et al. 2013) and the formation of ozone and aerosols (McDonald et al. 2018).

Exposure to fragranced laundry products has been associated with adverse effects on human health. Across four countries (the United States, Australia, the United Kingdom, and Sweden), an estimated $7.6 \%$ of adults, on average (12.5\% 6.1\% 6.0\% 5.6\% 7.6\%, respectively) report health problems when exposed to fragranced laundry products from dryer vents (Steinemann 2019). In earlier studies in the US, exposure to fragranced laundry products from dryer vents was associated with health problems for $10.9 \%$ of the general population and $21.2 \%$ of asthmatics (Caress and Steinemann 2009).

Ingredients in fragranced laundry products are not required to be fully disclosed, in any country (Lunny et al. 2017; Steinemann 2009). Thus, relatively little is known about specific chemical emissions and exposures. However, in previous chemical analyses of laundry products, terpenes were detected in fragranced laundry products but not in fragrance-free laundry products (Steinemann 2015, Nematollahi et al. 2019).

This study investigates the volatile emissions from fragranced laundry products, with a focus on dryer vents as a source of air pollutants that is largely unrecognized and unregulated. With research from across the United States (US) and Australia (AU), this study synthesizes and analyzes data and presents new findings on exposures, emissions, and effects.

The study pursues three main objectives: (a) to determine the frequency and types of health problems associated with exposure to fragranced laundry products from dryer vents, (b) to assess and compare the VOCs from fragranced and fragrance-free laundry products, and (c) to calculate potential reductions in limonene emissions from dryer vents by switching from fragranced to fragrance-free laundry products. Results can provide a scientific foundation and practical approach to reduce pollutants and potential health risks associated with the use of laundry products and their emissions through dryer vents. 


\section{Results and Discussion}

\section{Health effects associated with exposure to fragranced laundry products}

Nationally representative population-based surveys were conducted in the US $(n=1,136)$ and $\mathrm{AU}(\mathrm{n}=1,098)$ to assess use of fragranced laundry products, exposures, and reports of health effects. Details of the survey methodologies, data, and statistical analyses are provided in Steinemann (2016, 2017, 2018, 2019), Steinemann and Goodman (2019), and Steinemann and Nematollahi (2020). Results are presented in this section for the US and AU, respectively.

Across the US and AU, $88.4 \%$ and $89.3 \%$ of adults are exposed to fragranced laundry products at least once a week, from their own use $(84.1 \%, 84.30 \%)$, others' use $(47.4 \%$, $44.3 \%)$ or both $(88.4 \%$ and $89.3 \%)$.

Among the general population in the US and AU, $12.5 \%$ and $6.1 \%$ of adults report health problems when exposed to scented laundry products from dryer vents. Adverse health effects include respiratory problems (the most frequently reported, collectively), mucosal symptoms, skin problems, asthma attacks, migraine headaches, neurological problems, among others (see Tables 1 and 2).

For vulnerable sub-populations, the prevalence of adverse effects is higher (Tables 1 and 2). Among asthmatics in the US and AU, 28.9\% and 12.1\% report adverse effects when exposed to scented laundry products from dryer vents, with respiratory problems the most frequently reported. Among autistic adults, 71.4\% and 51.2\% report adverse effects, with immune system problems the most frequently reported. Among migraineurs, $40.8 \%$ and $29.1 \%$ report adverse effects, with asthma attacks the most frequently reported.

\section{Volatile emissions from fragranced and fragrance-free laundry products}

Using gas chromatography and mass spectrometry (GC/MS) headspace techniques, volatile emissions were analyzed from a collection of US and AU fragranced and fragrance-free laundry products. Analytical methods and further details are provided in Steinemann et al. (2015) and Nematollahi et al. (2019; 2018).

The most prevalent VOCs (in at least $20 \%$ of all 35 laundry products) analysed is provided in Table 3. Among all the 25 fragranced laundry products, the most common VOCs were limonene (92\% of products), alpha-pinene (68\%), beta-trans-ocimene $(64 \%)$, eucalyptol 
$(60 \%)$ and acetaldehyde (56\%). Among all the 10 fragrance-free laundry products, the most common VOCs were ethanol ( $80 \%$ of products) and acetaldehyde (60\%).

Comparing the VOCs emitted from fragranced laundry products and fragrance-free laundry products, all of the fragranced products contained terpenes, but none of the fragrance-free products contained terpenes (Table 3 ).

\section{VOC emissions from dryer vents and potential reductions}

Dryer vent emissions from seven households were analyzed for their limonene concentrations during three scenarios of laundry product use: fragranced laundry products (households \#1\#4, \#7-\#8), exclusively fragrance-free laundry products (households \#5-\#6), and after switching from fragranced products to fragrance-free products (households \#1-\#4). Results are provided in Table 4. Analytical methods and further details are provided in Steinemann et al. (2013) and Goodman et al. (2019).

In households that switched from fragranced products to fragrance-free products, emissions of limonene were reduced within two weeks by up to $99.7 \%$ (average $79.1 \%$ ). As context for the significance of switching from fragranced to fragrance-free products, the potential reduction in limonene emissions was calculated at both a household and regional level. (See Table 4 and Supplementary Material).

During use of fragranced laundry products, limonene emissions from dryer vents per household is estimated at 2.13 grams/year. After switching to fragrance-free laundry products, the average reduction in limonene emissions per household is estimated at 1.68 grams/year.

At a regional level, during use of fragranced laundry products, limonene emissions from dryer vents across metropolitan Melbourne is estimated at 1.99 tons/year. After switching to the fragrance-free laundry products, the average reduction in limonene emissions across metropolitan Melbourne is estimated at 1.58 tons/year.

In this same analytical approach, applied to the state of California, limonene emissions from dryer vents across the state was estimated at 10.95 tons/year. After switching to fragrancefree laundry products, the average reduction in limonene emissions across the state was estimated at 8.66 tons/year. The state of California is of particular interest because of efforts to reduce VOC emissions from use of fragranced consumer products (CARB 2019).

\section{Conclusion}


This study indicates that fragranced laundry products emitted from dryer vents can be sources of indoor and outdoor air pollutants and health risks. The study also indicates that switching from fragranced to fragrance-free laundry products can generate potential improvements for air quality and health.

\section{Acknowledgements}

We gratefully acknowledge the supporters of this study: the Clean Air and Urban Landscapes Hub funded by the Australian Government's National Environmental Science Program; and the Commonwealth Scientific and Industrial Research Organisation (CSIRO). We thank Professor Spas Kolev, School of Chemistry, The University of Melbourne, for his exceptional expertise and generosity, and for granting use of his laboratory facilities in Australia. We also thank Ian C. MacGregor of Battelle in Columbus, OH, USA, for his excellent analytic work in the United States. Finally, we deeply appreciate the anonymous reviewers of this paper. 


\section{References}

CARB (2019) California Air Resource Board, The California Consumer Products Regulation. Available at: https://ww3.arb.ca.gov/consprod/regs/2019/toc_final_5_2019.pdf

Caress SM, Steinemann AC (2009) Prevalence of Fragrance Sensitivity in the American Population. Journal of Environmental Health 71(7):46-50.

Goodman N, Nematollahi N, Agosti G, Steinemann A (2019) Evaluating air quality with and without air fresheners. Air Quality, Atmosphere \& Health. 13:1-4.

Goodman NB, Steinemann A, Wheeler AJ, Paevere PJ, Cheng M, Brown SK (2017) Volatile Organic Compounds within Indoor Environments in Australia. Building and Environment 122:116-125.

Jia C, Batterman S, Godwin C (2008) VOCs in industrial, urban and suburban neighborhoods, Part 1: Indoor and outdoor concentrations, variation, and risk drivers. Atmos. Environ. 42:2083-2100.

Lunny S, Nelson R, Steinemann A (2017) Something in the air but not on the label: a call for increased regulatory ingredient disclosure for fragranced consumer products. UNSWLJ, 40:1366-1391.

McDonald BC, De Gouw JA, Gilman JB, Jathar SH, Akherati A, Cappa CD, Jimenez JL, Lee-Taylor J, Hayes PL, McKeen SA, Cui YY (2018) Volatile chemical products emerging as largest petrochemical source of urban organic emissions. Science, 359(6377):760-764.

Nazaroff WW, Weschler CJ (2004) Cleaning products and air fresheners: exposure to primary and secondary air pollutants. Atmospheric environment 38(18):2841-2865.

Nematollahi N, Kolev SD, Steinemann, A (2019) Volatile chemical emissions from 134 common consumer products. Air Quality, Atmosphere \& Health, 12(11), pp.1259-1265.

Nematollahi, N., Doronila, A., Mornane, P.J., Duan, A., Kolev, S.D. and Steinemann, A., (2018) Volatile chemical emissions from fragranced baby products. Air Quality, Atmosphere \& Health, 11(7), pp.785-790.

Steinemann A (2019) International prevalence of fragrance sensitivity. Air Quality, Atmosphere \& Health. 12:891-897. 
Steinemann A (2018) Fragranced consumer products: effects on autistic adults in the United States, Australia, and United Kingdom. Air Quality, Atmosphere \& Health, 11(10), pp.11371142.

Steinemann A (2017) Health and societal effects from exposure to fragranced consumer products. Preventive medicine reports, 5:45-47.

Steinemann A (2016) Fragranced consumer products: exposures and effects from emissions. Air Quality, Atmosphere \& Health, 9(8):861-866.

Steinemann A (2015) Volatile emissions from common consumer products. Air Quality, Atmosphere \& Health, 8(3):.273-281.

Steinemann AC (2009) Fragranced consumer products and undisclosed ingredients. Environmental Impact Assessment Review, 29(1):32-38.

Steinemann AC, Gallagher LG, Davis AL, MacGregor IC (2013) Chemical emissions from residential dryer vents during use of fragranced laundry products. Air Quality, Atmosphere \& Health, 6(1):151-156.

Steinemann A, Nematollahi N (2020) Migraine headaches and fragranced consumer products: an international population-based study. Air Quality, Atmosphere \& Health, pp.1-4.

Steinemann A, Goodman N (2019) Fragranced consumer products and effects on asthmatics: an international population-based study. Air Quality, Atmosphere \& Health, 12(6):643-649.

US EPA (2008) United States Environmental Protection Agency, air quality system, raw data report (AMP350). Beacon Hill site, Seattle, WA. Report generated March 29, 2011

Wang CM, Barratt, B, Carslaw N, Doutsi A, Dunmore RE, Ward MW, Lewis AC (2017) Unexpectedly high concentrations of monoterpenes in a study of UK homes. Environ. Sci. Process Impacts 19:528-537. 
Table 1. Prevalence of health problems reported from exposure to fragranced laundry products

\begin{tabular}{|c|c|c|c|c|c|c|c|c|}
\hline & \multicolumn{2}{|c|}{ Gen Population } & \multicolumn{2}{|c|}{ Asthmatics } & \multicolumn{2}{|c|}{ Autistic Adults } & \multicolumn{2}{|c|}{ Migraineurs } \\
\hline & USA & AUS & USA & AUS & USA & AUS & USA & AUS \\
\hline \multirow[t]{2}{*}{ Total } & 1137 & 1098 & 305 & 313 & 49 & 41 & 179 & 110 \\
\hline & $100.0 \%$ & $100.0 \%$ & $100.0 \%$ & $100.0 \%$ & $100.0 \%$ & $100.0 \%$ & $100.0 \%$ & $100.0 \%$ \\
\hline \multirow[t]{2}{*}{ Yes } & 142 & 67 & 88 & 38 & 35 & 21 & 73 & 32 \\
\hline & $12.5 \%$ & $6.1 \%$ & $28.9 \%$ & $12.1 \%$ & $71.4 \%$ & $51.2 \%$ & $40.8 \%$ & $29.1 \%$ \\
\hline \multirow[t]{2}{*}{ No } & 906 & 909 & 193 & 231 & 14 & 18 & 76 & 59 \\
\hline & $79.7 \%$ & $82.8 \%$ & $63.3 \%$ & $73.8 \%$ & $28.6 \%$ & $43.9 \%$ & $42.5 \%$ & $53.6 \%$ \\
\hline \multirow[t]{2}{*}{$\begin{array}{l}\text { Don't } \\
\text { know/not } \\
\text { sure }\end{array}$} & 88 & 120 & 24 & 44 & - & 2 & 30 & 19 \\
\hline & $7.7 \%$ & $10.9 \%$ & $7.9 \%$ & $14.1 \%$ & - & $4.9 \%$ & $16.8 \%$ & $17.3 \%$ \\
\hline \multirow[t]{2}{*}{$\begin{array}{l}\text { Decline to } \\
\text { answer }\end{array}$} & 1 & 2 & - & - & - & - & 0 & 0 \\
\hline & $0.1 \%$ & $0.2 \%$ & - & - & - & - & - & - \\
\hline
\end{tabular}


Table 2. Types and prevalence of adverse health effects reported from exposure to fragranced laundry products

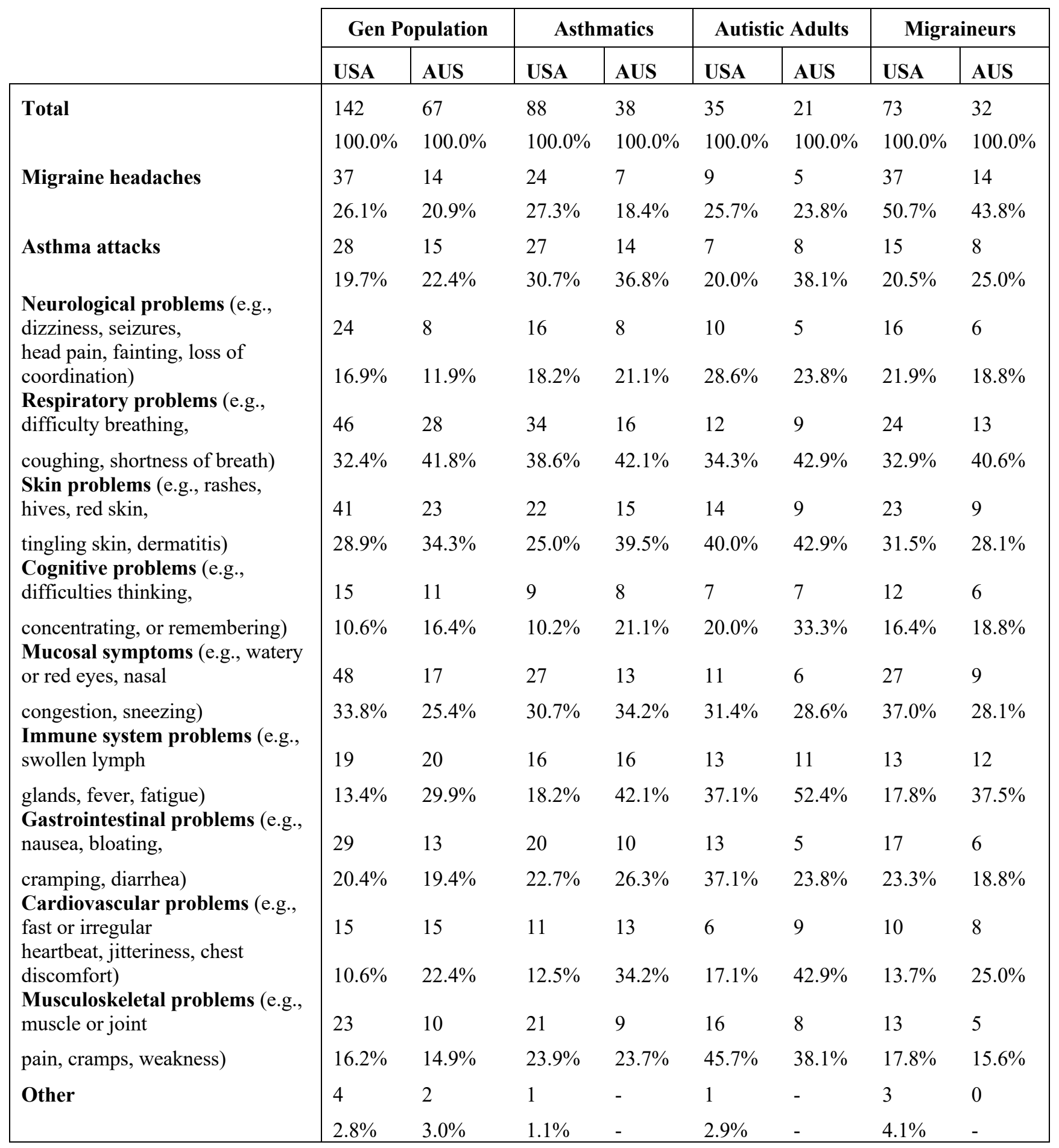


Table 3. Most prevalent VOCs emitted from fragranced and fragrance-free laundry products in US and AU

\begin{tabular}{|c|c|c|c|c|c|c|c|c|}
\hline Compound & CAS \# & $\begin{array}{l}\text { Total } \\
\text { products } \\
(\mathrm{n}=35)\end{array}$ & $\begin{array}{l}\text { Fragranced } \\
\text { US }(n=5)\end{array}$ & $\begin{array}{l}\text { Fragranced } \\
\text { AU }(n=20)\end{array}$ & $\begin{array}{l}\text { Total } \\
\text { Fragranced } \\
(\mathrm{n}=25)\end{array}$ & $\begin{array}{l}\text { Fragrance- } \\
\text { free US } \\
(\mathrm{n}=6)\end{array}$ & $\begin{array}{l}\text { Fragrance- } \\
\text { free AU } \\
(n=4)\end{array}$ & $\begin{array}{l}\text { Total } \\
\text { Fragrance- } \\
\text { free } \\
(\mathrm{n}=10)\end{array}$ \\
\hline Limonene* & $138-86-3$ & 23 & 5 & 18 & 23 & & & \\
\hline Acetaldehyde** & $75-07-0$ & 20 & 2 & 12 & 14 & 4 & 2 & 6 \\
\hline Ethanol* & $64-17-5$ & 20 & 5 & 7 & 12 & 6 & 2 & 8 \\
\hline alpha-Pinene & $80-56-8$ & 17 & 4 & 13 & 17 & & & \\
\hline $\begin{array}{l}\text { beta-trans- } \\
\text { Ocimene }\end{array}$ & $3779-61-1$ & 16 & & 16 & 16 & & & \\
\hline Eucalyptol & $470-82-6$ & 15 & 1 & 14 & 15 & & & \\
\hline beta-Myrcene & $123-35-3$ & 12 & & 12 & 12 & & & \\
\hline Camphene & $79-92-5$ & 10 & 1 & 9 & 10 & & & \\
\hline Terpinolene & $586-62-9$ & 10 & 2 & 8 & 10 & & & \\
\hline gamma-Terpinene & $99-85-4$ & 10 & 2 & 8 & 10 & & & \\
\hline Acetone* & $67-64-1$ & 10 & 2 & 5 & 7 & 2 & 1 & 3 \\
\hline Dihydromyrcenol & $18479-58-8$ & 9 & & 9 & 9 & & & \\
\hline beta-Pinene & $127-91-3$ & 9 & 5 & 4 & 9 & & & \\
\hline Methanol** & $67-56-1$ & 8 & 1 & 3 & 4 & 4 & & 4 \\
\hline beta-Phellandrene & $555-10-2$ & 7 & 1 & 6 & 7 & & & \\
\hline Linalool & $78-70-6$ & 7 & 2 & 5 & 7 & & & \\
\hline Isopropyl alcohol* & $67-63-0$ & 7 & 1 & 5 & 6 & 1 & & 1 \\
\hline
\end{tabular}

Classified as potentially hazardous according to

* Hazardous Chemical Information System (HCIS), Safe Work Australia (SWA, 2020)

** Hazardous Air Pollutants (HAPs), United States Environmental Protection Agency (EPA 2017), as well as

HCIS (SWA, 2020)

Note: Compounds with total prevalence less than 3 were not included herein. 
Table 4. Emissions of limonene from dryer vents in US and AU

Concentration of limonene during use of fragranced and fragrance-free laundry products

\begin{tabular}{|c|c|c|c|c|c|}
\hline $\begin{array}{c}\text { Household } \\
\text { and Product } \\
\text { Type }\end{array}$ & $\begin{array}{c}\text { During use of } \\
\text { Fragranced } \\
\text { products } \\
\left(\mu \mathrm{g} / \mathrm{m}^{3}\right)\end{array}$ & $\begin{array}{c}\text { Emissions of } \\
\text { Limonene per } \\
\text { household } \\
\text { (g/year) }\end{array}$ & $\begin{array}{c}\text { During use } \\
\text { of } \\
\text { Fragrance- } \\
\text { Free } \\
\text { products } \\
\left(\mu \mathrm{g} / \mathrm{m}^{3}\right)\end{array}$ & $\begin{array}{c}\text { Emissions of } \\
\text { Limonene per } \\
\text { household } \\
\text { (g/year) }\end{array}$ & $\begin{array}{c}\text { Percentage reduction in } \\
\text { d-limonene } \\
\text { (mass of limonene } \\
\text { reduced per } \\
\text { household/year) }\end{array}$ \\
\cline { 2 - 6 } & sample $(a)$ & estimate $(a)$ & sample $(b)$ & estimate $(b)$ & $(a-b) /(b)$ \\
\hline$\# 1(\mathrm{~F}$ to FF) & 2.35 & 0.15 & 1.50 & 0.09 & $36.2 \%(0.05 \mathrm{~g})$ \\
\hline$\# 2(\mathrm{~F}$ to FF) & 10.52 & 0.67 & 0.13 & 0.01 & $98.8 \%(0.66 \mathrm{~g})$ \\
\hline$\# 3(\mathrm{~F}$ to FF) & 2.51 & 0.16 & 0.46 & 0.03 & $81.7 \%(0.13 \mathrm{~g})$ \\
\hline$\# 4(\mathrm{~F}$ to FF) & 118 & 7.54 & 0.36 & 0.02 & $99.7 \%(7.51 \mathrm{~g})$ \\
\hline$\# 5(\mathrm{FF})$ & - & - & 0.26 & 0.02 & \\
\hline$\# 6(\mathrm{FF})$ & - & - & 0.24 & 0.02 & \\
\hline$\# 7(\mathrm{~F})$ & 9.3 & 0.59 & & & \\
\hline$\# 8(\mathrm{~F})$ & 14.7 & 0.93 & & & \\
\hline
\end{tabular}

$\mathrm{F}=$ fragranced laundry products; $\mathrm{FF}=$ fragrance-free laundry products

Household \#1-\#6 AU; Household \#7-\#8 US 


\section{Limonene mass estimation for metropolitan Melbourne AU}

Calculations assumptions and sources:

Data based on the year 2016 census: 1,832,043 households in Greater Melbourne (ABS, 2017); $55 \%$ of households have clothes dryers (Sustainability Victoria, 2016); dryer vent flow rate $=200$ cfm or $339.8 \mathrm{~m}^{3} /$ hour (State of Wisconsin Department of Commerce 2001); 180 loads per year each taking approximately 62.5 minutes $=188$ hours drying/year per household (Sustainability Victoria, 2016); $33.34 \mu \mathrm{g} / \mathrm{m}^{3}$ emissions of limonene after using fragranced laundry detergent (average of each site, $2.35 \mu \mathrm{g} / \mathrm{m}^{3}, 10.52 \mu \mathrm{g} / \mathrm{m}^{3}, 2.51 \mu \mathrm{g} / \mathrm{m}^{3}$, and $118 \mu \mathrm{g} / \mathrm{m}^{3}$ from this study); $84.3 \%$ of households use fragranced laundry products at least once a week (Steinemann, 2017); $79.1 \%$ average reduction in limonene after switching to fragrance-free detergent (Goodman et al., 2019).

Calculation of annual mass for metropolitan Melbourne AU:

$1,832,043$ households $\times 0.55 \times 339.8 \mathrm{~m}^{3} / \mathrm{h}$ x $188 \mathrm{~h} \times 33.34 \mu \mathrm{g} / \mathrm{m}^{3}\left(\mathrm{x} 1 \mathrm{E}^{-6} \mathrm{~g}\right) \times 0.843 \times \mathrm{x}^{-6}$ tonne $)=1.80$ tonne/year or 1.99 tons/year $(1,000 \mathrm{~kg}=1$ tonne; $907.2 \mathrm{~kg}=1 \mathrm{ton})$

Reduction in limonene after switch to fragrance-free detergent: 1.58 tons/year.

Calculation of the annual mass of limonene per household for metropolitan Melbourne AU:

$339.8 \mathrm{~m}^{3} / \mathrm{h} \times 188 \mathrm{~h} \times 33.34 \mu \mathrm{g} / \mathrm{m}^{3}\left(\mathrm{x} 1 \mathrm{E}^{-6} \mathrm{~g}\right)=2.13 \mathrm{grams} /$ year

Reduction in limonene per household after switch to fragrance-free detergent: 1.68 grams/year (i.e., $79.1 \%$ of 2.13 grams/year) 


\section{Limonene mass estimation for California}

Calculations assumptions and sources:

Data based on the 2014-2018 US Census Bureau data: 12,965,435 households in California (US Census Bureau, 2020); 83.4\% of households have clothes dryers (US Department of Commerce, 2013); dryer vent flow rate $=200 \mathrm{cfm}$ or $339.8 \mathrm{~m}^{3} /$ hour (State of Wisconsin Department of Commerce 2001); 268 hours drying/year per household (US DOE, 2009); $12.0 \mu \mathrm{g} / \mathrm{m}^{3}$ emissions of limonene after using fragranced laundry detergent (average of each site, $9.3 \mu \mathrm{g} / \mathrm{m}^{3}$ and 14.7 $\mu \mathrm{g} / \mathrm{m}^{3}$ (Steinemann et al. 2013); 84.1\% of households use fragranced laundry products at least once a week (Steinemann, 2016); 79.1\% average reduction in limonene after switching to fragrance-free detergent (Goodman et al., 2019).

Calculation of annual mass for California US:

$12,965,435$ households $\times 0.834 \times 339.8 \mathrm{~m}^{3} / \mathrm{h} \times 268 \mathrm{~h} \times 12.34 \mu \mathrm{g} / \mathrm{m}^{3}\left(\mathrm{x} 1 \mathrm{E}^{-6} \mathrm{~g}\right) \times 0.841 \times\left(1 \mathrm{E}^{-6}\right.$ tonne $)=9.94$ tonne/year or 10.95 tons/year. $(1,000 \mathrm{~kg}=1$ tonne; $907.2 \mathrm{~kg}=1 \mathrm{ton})$

Reduction in limonene after switch to fragrance-free detergent: 8.66 tons/year.

Calculation of the annual mass of limonene per household for California US:

$339.8 \mathrm{~m}^{3} / \mathrm{h} \times 268 \mathrm{~h} \times 12 \mu \mathrm{g} / \mathrm{m}^{3}\left(\mathrm{x} 1 \mathrm{E}^{-6} \mathrm{~g}\right)=1.09$ grams $/$ year

Reduction in limonene per household after switch to fragrance-free detergent: 0.86 grams/year (i.e., $79.1 \%$ of 1.09 grams/year) 


\section{References}

ABS (2017) Australian Bureau of Statistics. 2016 Census QuickStats. Website:

https:/quickstats.censusdata.abs.gov.au/census services/getproduct/census/2016/quickstat/2GMEL?o pendocument. Accessed 20:59 on August 12, 2020

ABS (2008). 4602.0. 55.001-Environmental issues: Energy use and conservation. Australian Bureau Statistics. Website: https://www.abs.gov.au/ausstats/abs@.nsf/mf/4602.0.55.001/ Accessed 21:30 on August 12, 2020

State of Wisconsin Department of Commerce (2001) Optional Uniform Dwelling Code (UDC) makeup and combustion air worksheet, April 2001. http://commerce.wi.gov/sb/. Accessed 4/16/10

Steinemann A 2017. Health and societal effects from exposure to fragranced consumer products, Preventive Medicine Reports, 5:45-47

Steinemann A 2016. Fragranced consumer products: exposures and effects from emissions. Air Quality, Atmosphere \& Health 9(8):861-866.

Sustainability Victoria (2016). Clothes Dryer Retrofit Trial. Authorised and published by Sustainability Victoria, Level 28, Urban Workshop, 50 Lonsdale Street Melbourne Victoria 3000 Australia. ISBN 978-1-920825-17-1

US Census Bureau (2020) Census Quick Facts California. Website:

https://www.census.gov/quickfacts/CA Accessed 9:54 am on August 19, 2020

US Department of Commerce (2013) Extended Measures of Well-Being: Living Conditions in the United States: 2011. Available at: https://www.census.gov/history/pdf/sipp-data-appliances.pdf

US DOE (2009) 2009 Buildings energy data book, U.S. Department of Energy, Energy Efficiency and Renewable Energy, October 2009 